behind licensee immunity is the same policy reflected in existing libel ductrines. Protection of the innocent few who may be deprived of a valid cause of action is too expensive if the cost is the risk of inhibiting free political expression. With crucial, and probably bitter, national elections this year, it is important that Congress act promptly to amend section 315 .

of suits does indicate that the number of potential victims deprived of a remely by a statutory immunity would be negligible. 


\section{GRATUITOUS FINDINGS OF VALIDITY: A JUDICIAL GIFT TO PATENTEES*}

Patents are granted by the government to promote the development of science and the useful arts. ${ }^{1}$ Theoretically, applicants must demonstrate true inventiveness. ${ }^{2}$ In practice, however, the patent office does not make an exhaustive search of every field in which a patent application is presented." Consequently, a patent is often granted though closer scrutiny would have blocked approval. An undeserving patentee may thus enjoy a windfall grant.

Such a patent may be eliminated, however, if the patentee sues for its infringement. ${ }^{4}$ To win an infringement suit a plaintiff not only must have a valid

*Wabash Corp. v. Ross Electric Corp., 187 F.2d 577 (2d Cir. 1951), cert. deniv'l, 20 U.S.L. WeEk 3089 (Oct. 9, 1951).

1. "The Congress shall have power ... to promote the progress of Science and useful arts by securing for limited times to authors and inventors the exclusive right to thir respective writings and discoveries." U.S. Const. Art. I $\$ 8$.

The wording of the Constitution indicates that the patent system was established primarily for the benefit of society as a whole. The reward to the individual inventor is designed to encourage new discoveries. It is not an end in itself. See Bennett, Tin American Patent System 54-6 (1943). For a severe criticism of the view that the inventor's property right in the patent is paramount, see HAMuLTON, PATENTS AND FikE: ENTERIRISE 51-70 (TNEC MoNograph 31, 1941).

2. "Any person who has invented or discovered any new and iscful art, machine, manufacture, or composition of matter, or any $n c w$ and usefil improvements thercof . . . may . . obtain a patent therefor." Rev. STAT. $\$ 4886$ (1897), as amended, 35 U.S.C. $\S 31$ (1950). (emphasis added).

3. Between sixty and ninety-five thousand patent applications are presented to the patent office annually. Each examiner must pass on at least twelve per week bectusc the office is seriously understaffed. Only a few hours can be devoted to a task which would take days or even weeks, if properly done. And "searching" becomes evell moro slow and difficult as the arts multiply.

Appeal to the Court of Customs and Patent Appeals can be taken only when the patent is denied. And patent office tradition considers an examiner incompetent if more thitu one third of his decisions are appealed and reversed. These conditions encourage cetsy" approval of patent applications. See Kenyon, Patent Law, 35 A.B.A.J. 480, 482 (1949), and Haniliton, Patents and Free Enterprise 124-5, 127 (TNEC Monograph 31, 1941).

The patent office has been criticized, moreover, for determining patentability by a low standard of invention. Sec Great Atlantic \& Pacific Tea Co. v. Supermarket Corp., 340 U.S. 147, 155-6 (1950) (concurring opinion).

4. Infringement is the unauthorized manufacture, sale, or use of a patented article during the life of the patent. The patentee's remedy for such an invasion of his rights may consist of damages and an injunction against further infringement. Both remedies are obtainable in one suit in a Federal District Court. Hosr, PATENT TACtics ANv Law 216, 222 (1950).

The validity of patents is usually challenged in suits for their infringement. However, other situations in which it may be disputed are:

(1) a declaratory judgment action by an alleged infringer against a patentec who has been harassing him with threats of suit. HoAR, PATENT TACTICS AND I.AW 222 (1950); 
patent, but also must show that the defendant infringed it." Accordingly, either non-infringement or invalidity defeats his cause. ${ }^{5}$ Thus, a court can dismiss the complaint on the ground of non-infringement or invalidity, or both. ${ }^{7}$ And a decree of invalidity will discourage further litigation on that patent. $^{8}$ As a result, an area formerly monopolized ${ }^{9}$ is reopened to the public. ${ }^{10}$

Federico, Operation of the Fedcral Declaratory Indgment Act in Patent Cases, 19 J. Pat. OFf. Soc'y 489 (1937).

(2) a suit for canceliation of a patent by the government against a patentee. The United States may bring such a suit only if it can allege that the patent was fraudulently procured. United States v. American Bell Telephone Co., 167 U.S. 224 (1S97). Fraud in this sense refers to any intentional misrepresentation made by the patentee to patent office officials which induced them to grant him his patent. See, c.g., United States v. Flartford Empire Co., 73 F. Supp. 979 (D. Del. 1947) (patentee deceived ratent office as to authorship of article describing its invention as a remarlable advance in the art); United States v. Cold Metal Process Co., 164 F.2d 754 (6th Cir. 1947), cert. dcuicd, 334 U.S. 811 (1948) (patentee allegedly failed to disclose knowledge of the prior art).

(3) an antitrust proceeding by the gorernment against a patentce, where the esistence of the patent is offered as a defense. United States v. Gypsum Co., 333 U.S. 364 (1947); Hoar, Patent Tactics and Law 297 (1950).

(4) a suit for royalties by patent holder against licensee. A licensee is ordinarily estopped from denying the validity of the patent under which he has been licensed, but not if he alleges that the patentee has misused his patent in some way, c.g., in viulation of the antitrust laws. Automatic Radio Manufacuring Co. v. Hazeltine Research, 339 U.S. 827 (1949) ; Katzinger Co. v. Chicago Metallic Mffg. Co., 330 U.S. 394 (1946); Sola Electric Co. v. Jefferson Electric Co., 317 U.S. 173 (1942).

5. The plaintiff has the burden of proving that his patent has been infringed by the defendant. Hatmaker v. Dry Miik Co., 34 F.2d 609 (2d Cir. 1929). The patent itself, however, is presumed valid by virtue of its grant from the patent office. Thereiore, the burden of going forward with the evidence of its invalidity is on the defendant. Crosley Corp. v. Westinghouse Electric \& MIfg. Co., 152 F.2d $\$ 95$ (3rd Cir. 1945).

6. Even where the defendant does not contest validity, plaintiff may lose if the invalidity of his patent is obvious on the face of the record. See, c.g., Slawson v. Grand Street R.R. Co., 107 U.S. 649, 652 (1882) ; Cridlebaugh v. Rudolph, 131 F.2d 795, S00 (3d Cir. 1942).

7. See, e.g., Hale v. General Motors Corp., 147 F.2d 383 (1st Cir. 1945) (dismissed on non-infringement alone) ; B. F. Sturtevant Co. v. Mass. Hair \& Felt Co., 122 F.2d 900 (1st Cir. 1941) (dismissed on invalidity alone); Alexander J. Bocz v. Hudson Motor Car Co., 19 F. Supp. 385 (E.D. Mich. 1937) (dismissed on both grounds).

A court may declare a patent invalid for any one of several reasons. Typical grounds for invaliditation are lack of inventive ingenuity; lack of novelty; lack of utility; anticipation in the prior art; or abandonment of the invention to the public domain. Ho.n, Patent Tactics and Law 35-49, 70 (1950).

8. Although the decree binds only the immediate parties to the suit and does not preclude a subsequent suit on the same patent against a different defendant, it places the patentee at a disadvantage in later litigation. The earlier decision will prebably be accorded great weight unless the patent owner can show that it was the result of gross error. See Triplett v. Lowell, 297 U.S. 638 (1936) ; Shaler Co. v. Riteway Prodicts, Inc., 19 F. Supp. 804 (W.D. Tenn. 1937) ; Bellows-Claude Neon Co. v. Sun Kay Gas Corp. 39 F.2d 907 (N.D. Ohio 1929); 12 GEo. W.ssr. L. Rev. 109 (1943).

9. Since the patent grant entitles the inventor to exclude all others from maling, using, and selling the patented device for 17 years, it is referred to as a "monopoly" by writers in the field. See Bennetr, The Anericin Patent Systes 79-141 (1943) and Hayilion, Patents and Free Enterprise 71-109 (TNEC Mlonograph 31, 1941) for a description of the extent of the monopoly allowed to a patentee.

10. See, e.g., Addressograph-MIultigraph Corp. v. Cooper, 156 F.2d 483, 485 (2i Cir. 1946). 
Doubtless the Supreme Court has recognized that a decree of invalidity benefits the public. Six years ago, upholding a trial court's invalidation of a patent, it described full inquiry into the issue of validity as usually the "better practice" in infringement suits. ${ }^{11}$ Many District Courts had avoided declaring patents invalid, disposing of as many cases as they could on the sole ground of non-infringement. ${ }^{12}$ The Supreme Court statement encouraged them instead to hold patents both invalid and non-infringed whenever possible. ${ }^{13}$ But the ambiguous Supreme Court dictum ${ }^{14}$ has received another twist. Courts have read it as prescribing a declaration of validity where the evidence supports such a finding, even though judgment must go for the defendant on the ground of non-infringement. ${ }^{15}$

A recent Circuit Court decision, Wabash Corp. v. Ross Elcctric Corp., ${ }^{10}$ focuses the clash of conflicting interpretations. The district court had held a patent uninfringed, but went on to make a finding of validity. ${ }^{17}$ On appeal, the circuit court unanimousiy agreed on non-infringement, ${ }^{18}$ but split on the appropriateness of the validity finding. One judge commended the lower

11. "There has been a tendency among the lower federal courts in infringement stits to dispose of them on the ground of non-infringement without going into the question of the validity of the patent. It has come to be recognized, however, that of the two questions, validity has the greater public importance, and the District Court in this case followed what will usually be the better practice by inquiring fully into the validity of this patent." Sinclair \& Carroll Co. v. Interchemical Corp., 325 U.S. 327, 330 (1945).

12. See National Development Co. v. Lawson-Porter Shoe Mach. Corp., 129 F.2d 255, 260, (1st Cir. 1942); Aero Spark Plug Co. v. B.G. Corp., 130 F.2d 290, 292 (2d Cir. 1942); Woodward, A Reconsideration of the Patent System as a Problem in Administrative Lazw, 55 HARv. L. REv. 950, 957 (1942).

Other federal courts, in recognition of the service rendered the public by a decree of invalidity, had the policy of declaring patents invalid whenever the evidence warranted such a holding. See, e.g., Densmore v. Scofield, 102 U.S. 375 (1880); Cover v. Schwartz, 133 F.2d 541, 545 (2d Cir. 1942).

13. See, e.g., Addressograph-Multigraph Corp. v. Cooper, 156 F.2d 483, 485 (2d Cir. . 1946) ; Palmer v. Sun Oil Co., 78 F. Supp. 38, 55 (N.D. Ohio 1948).

14. Sinclair \& Carroll Co. v. Interchemical Corp., 325 U.S. 327, 330 (1945). Sce note 11 supra.

15. E.g., Holland Co. v. American Steel Foundries, 190 F.2d 37 (7th Cir. 1951); Pennington Engineering Co. v. Spicer Mfg. Co., 165 F.2d 59, 61 (6th Cir. 1947) ; Galston, The Pateint in Court Infringement, 11 F.R.D. 319, 324 (1951).

16. 187 F.2d 577 (2d Cir. 1951).

17. 89 F. Supp. 720 (E.D. N.Y. 1950).

18. 187 F.2d 577 (2d Cir. 1951). The patent which the lower court found valid, though uninfringed, was a process patent. On that patent, its decision was affirmed, Judge A. Hand speaking for the majority of the court, and Judge Chase concurring without reservation. Judge Frank, though concurring on the ground of non-infringement, strongly protested the majority's refusal to disturb the lower court's finding of validity. The other patent involved was a product patent which the lower court held valid and infringed. Its decision on that patent was reversed, Judge Fland again speaking for the majority, Judge Frank concurring, and Judge Chase dissenting. 
court for finding the patent valid though not infringed, and quoted the Supreme Court statement as authority for that practice. ${ }^{10}$ Another violently disagreed, denying that the Supreme Court ever intended to authorize such a finding. And he argued further that the finding of validity should be expunged from the record. ${ }^{20}$

Generally speaking, a trial court should make findings of fact on all relevant issues. ${ }^{21}$ Federal Rule $52(\mathrm{a})$, in accord with this aim, directs courts trying cases without juries to make special findings of fact and separate conclusions of law. ${ }^{22}$ Thus, the initial trier of facts, best able to evaluate oral testimony, makes its considered findings available to the appellate tribunal. ${ }^{23}$ A full set of findings may enable the appellate court to dispose finally of litigation, though reversing a judgment by the trial court. When findings have once been made, a remand is no longer needed and the suit can be terminsted without further delay. ${ }^{24}$

19. 187 F.2d 577, 581 (2d Cir. 1951) (partially dissenting opinion).

20. 187 F.2d 577, 586-605 (2d Cir. 1951) (partially concurring and partially dissenting opinion). One of Judge Frank's main arguments for expunging the finding of validity from the record is based on Electrical Fittings Corp. v. Thomas \& Eetts Co., 307 U.S. 241 (1939). But Electrical Fittings does not govern the principal ease. There, the Supreme Court reviewed a finding that plaintiff's patent was valid, though not infringed, and expunged the finding of validity only because it was incorporated in the decree. Id. at $242 .^{\circ}$ Since it was part of the decree, even though unessential to the judgment, it would have estopped the defendant from challenging the validity of plaintiff's patent in a later suit. Ibid.; Oliver-Sherwood Co. v. Patterson-Ballagh Corp., 95 F.2d 70 (9th Cir. 1938). In the principal case, on the other hand, the decree did not include the finding of validity. Consequently, the defendant would not be bound by that finding in a subsequent suit. Scott, Collateral Estopfel by Judgment, 56 Hanv. L. Rev. 1, 14-18 (1942); Restatenient, Judgenients, \$6\$ c. 3 (1942); id. \$69 c. 3.

Nor should such a finding influence a court in later litigation betwcen plaintifi and other defendants. Courts should not regard findings which are not necessary to support the judgment as persuasive precedent. See Wash., Alex \& G. P. Co. v. Sicliles, 5 Wall. 580,592 (U.S. 1866)) ; Smith v. Miosier, 169 F. 430,446 (N.D. N.Y. 1909).

21. Such findings serve a threefold purpose. They (1) evolee eare on the part of the trial judge in his ascertainment of the facts, (2) define the issues adjudicated for the purpose of res judicata and collatoral estoppel, and (3) aid the appellate court. Sce Notes to the Rutes of Civm. Procedure for the District Courts $6 S$ (1946); 5 Mioje, Federax Practice 2653 (1951).

22. "In all actions tried upon the facts without a jury, or with an advisory jury, the court shall find the facts specially and state separately its conclusions of law thereon and direct the entry of the appropriate judgment." FED. R. CIv. P. 52 (a).

23. Rule 52(a) admonishes appellate courts to give due regard "to the opportunity of the trial court to judge the credibility of the vitnesses." FED. R. Crv. P.

The importance of this function of the trial court is aclmowledged and emplasized in many cases. E.g. United States v. Yellow Cab Co., 338 U.S. 338, 341-2 (1949); Nee v. Linwood Securities Co., 174 F.2d 434, 437 (Sth Cir. 1949); United States v. Aluminum Co., 148 F.2d 416, 433 (2d Cir. 1945).

24. If the lower court fails to state the facts on which its judgment depends, the appellate court will ordinarily remand the case to have the essential findings supplied. See Hunter v. Scruggs Drug Store, 113 F.2d 971 (4th Cir. 1940); McClure v. O'Henry 
But the basic premises underlying Rule 52(a) do not always apply. A trial court's unnecessary finding of validity can only aid an appellate court that reverses the holding of non-infringement. ${ }^{25}$ However, decrees of noninfringement are seldom reversed. ${ }^{26}$ And even when they are, the appellate court may often conclude the case without remanding for further findings. Remand will not be needed unless the evidence on the issue of validity consisted in conflicting oral testimony. ${ }^{27}$ And in patent litigation physical exhibits and documentary evidence are often decisive of the issues. ${ }^{28}$ Thus findings of validity do not invariably help the appellate court.

Moreover, in no event can Rule 52(a) be construed as requiring findings on issues that do not dispose of the case. ${ }^{20} \mathrm{~A}$ finding of validity serves no legal function when there has been no infringement-the defendant at this point has prevailed. Unlike a holding of invalidity, it is not an alternative ground for decision. In short, when there is no infringement, it is mere dictum. ${ }^{\mathbf{3 0}}$

Needless findings of validity not only are procedurally unwarranted but are substantively defective. Validity may not be adequately contested where there has been no infringement. A defendant who can easily prove he has not

Tent \& Awning Co., 184 F.2d 636, 639 (7th Cir. 1950); 5 MIoore, Federal Puacrice 2662 (1951).

25. Then it would have to make a decision on the issue of validity before it could decide the case. Infringement, alone, is not sufficient ground for a decision in favor of the plaintiff. In order to find for the plaintiff. the court must hold that his patent is valid as well as infringed. See page 99 supra.

26. In 1948, 1949, and 1950 twenty decisions of non-infringement were appealed. Of those twenty, only two were reversed or remanded. Helbush v. Finkle, 170 F.2d 41 (9th Cir. 1948) ; Florence-Mayo Nuway Co. v. Hardy, 168 F.2d 778 (4th Cir. 1948),

27. See United States v. Gypsum Co., 333 U.S. 364, 394-6 (1948); Dollar v. Liund, 184 F.2d 245, $248-9$ (D. C. Cir. 1950); Orvis v. Higgins, 180 F.2d 537, 539-40 (2d Cir. 1950); Wabash Corp. v. Ross Electric Corp., 187 F.2d 577, 597-600 (2d Cir. 1951) (partially concurring and partially dissenting opinion). But sce Heim v. Universal Pictures Co., Inc., 154 F.2d 480, 491 (2d Cir. 1946) (concurring opinion); Orvis v. Higgins, supra at 541-2, (dissenting opinion). For a thorough discussion of the problem, sce 5 Moore, Federal Practice 2637-42, 2662-4 (1951).

28. See, e.g., United States v. Gypsum Co., 333 U.S. 364, 395 (1947); and Smith v. Hall, 301 U.S. 216,228 (1937), where documentary evidence proved decisive of the question of validity.

29. See 5 Moore, Federal Practice 2659-61 (1951); Nordbye, Improucments in Statements of Findings of Fact \& Conclusions of Law, 1 F.R.D. 25, 33 (1940); and 4 WaLKer, Patents $\$ 900 B$ (Deller's edition 1937) on Equity Rule 703/2, which is substantially equivalent to the present Rule 52(a); Notes to TuE Rules of Civit. Procedure for the District Courts 46 (1938).

30. Electrical Fittings Corp. v. Thomas \& Betts Co., 307 U.S. 241 (1939) (finding of validity deleted from decree of non-infringement because immaterial to the disposition of the cause); Cover v. Schwartz, 133 F.2d 541 (2d Cir. 1942) (court cannot find uninfringed patent valid since there is no "case" or "controversy" justifying a decision in plaintiff's favor once the issue of infringement has been decided against him).

See also Altvater v. Freeman, 319 U.S. 359, 363 (1943); Scott, supra, note 20, at 18; and Judge Frank's opinion in Wabash Corp. v. Ross Electric Corp., 187 F.2d 577, 589 (2d Cir. 1951). 
infringed will not always go to the trouble and expense of attacking the validity of a patent. ${ }^{31}$ Therefore, the only substantial evidence before the court on that issue may be the plaintiff's. Certainly this is a dubious basis for a determination of validity.

Even if validity has been fully contested, a finding may be premature. A prior invention nullifying plaintiff's patent may not be known at the time of trial. It may have been laid away and forgotten for years.2 Or, it may be deliberately concealed by the owner if a patentee has paid him for suppressing the invention. ${ }^{33}$ In that case, even diligent search and thorough contest by an alleged infringer might not aid the court in reaching the correct conclusion. ${ }^{32}$ And it will have gone out of its way to pronounce a patent valid that ampler evidence might have invalidated.

But, more important, a patentee may exploit unnecessary findings to stifle competition in the area insulated by his grant. Since patent litigation is a costly matter, competitors carefully weigh their chances of success before undertaking the defense of an infringement suit. ${ }^{35}$ If the patentee can bacl his

31. Of seventy-seven patent attorneys asked whether they contest the issue of validity to the fullest when they can easily defend on the ground of non-infringement, fiftyeight replied. Thirty-two replied in the negative, twenty-six in the affirmative.

See, e.g., Slawson v. Grand Street R.R. Co., 107 U.S. 649, 652 (1882); and Cridlebaugh v. Rudolph, 131 F.2d 795, 800 (3d Cir. 1942). In neither ease was validity disputed, though the patents sued on were held invalid.

Since non-infringement alone is a complete defense to an iniringement suit, there is no legal requirement that validity be contested. See page 99 supra. A defendant with limited funds will surely consider carefully the cost of a careful search of the prior art, preferably by an expert, who must be well compensated. Free searches, though available, are generally worthless. And good searches may cost as much as \$100,000. Hoar, Patent Tactics and Law 254, 257 (1950); Woodward, A Reconsidcrations of the Patent System as a Problen in Administratia' Lani, 55 Harv. L. Rev. 950, 953 (1942). Furthermore, the additional defense will prolong the litigation. And costs, including attorney's fees, charges for transcripts of testimony, and compensation of expert witnesses, will rise accordingly. Bennetr, The American Patent Systers 106-107 (1943).

32. The response to a questionnaire addressed to seventy-seven patent lawyers throughout the country indicates that relevant evidence, which has remained undiscovered after thorough search, may be disclosed by accident. Forty-five of the sixty-one attorneys who replied said that they either had had such an experience or lnew of one-

33. For an example, see Hodn, Pateni Tactics axd Law 277 (1950).

34. Compare Smith v. Snow, 294 U.S. 1 (1934) (Smith patent held valid and infringed), with Smith v. Hall, 301 U.S. 216 (1936) (Smith patent held invalid); and compare United Chromium v. International Silver Co., 60 F.2d 913 (2d Cir. 1932) (Fink patent held valid and infringed), zith United Chromium, Ine v. General Motors Corp., 85 F.2d 577 (2d Cir. 1936) (Fink patent held invalid). In both situations, the courts reversed themselves when new evidence was nresented.

35. In affirmation of the fact that the high cost of patent litigation operstes as a deterrent to competitors who might otherwise defend infringement suits, see H.1ssuro:;, Patents and Free Enterprise 47-8, 111, 141-42 (TNEC Mlonograph 31, 1941); Benneter, The Arrertcan Patent Systear 106 (1943); Woodward, A Rcconsidcralion of the Patent System as a Problem in Administratize Laa, $55 \mathrm{HABr}$. L. Rov. 950, 957, 976 (1942). 